\title{
GENERAL CONCEPT AND COMPONENTS OF FAIR TRADE: THEORY AND INTERNATIONAL PRACTICE
}

\author{
Elena Dovgal \\ D. Sc. (Economics), Professor \\ Arthur Golikov International Economic Relations Department \\ V.N. Karazin Kharkiv National University \\ Svobody sq., 6, Kharkiv, Ukraine, 61022 \\ e-mail: e.dovgal@karazin.ua \\ ORCID: https://orcid.org/0000-0003-3219-9731 \\ Scopus Author ID: https://www.scopus.com/authid/detail.uri?authorId=57217603375 \\ Georgiy Dovgal \\ PhD (Economics), Associate Professor \\ Department of Travel Business and Country Studies \\ V.N. Karazin Kharkiv National University \\ Svobody sq., 6, Kharkiv, Ukraine, 61022 \\ e-mail: g.dovgal@karazin.ua \\ ORCID: https://orcid.org/0000-0002-0644-1793
}

\begin{abstract}
The relevance of the study is due to the fact that since 2017 , official documents and statements of the US administration, among other things, place the main emphasis on the so-called fair trade. One of the promises of the future president during his election campaign was the withdrawal from the Trans-Pacific Partnership (TPP), the revision of the NAFTA Agreement (North American Free Trade Agreement - North American Free Trade Agreement) and support for new trade agreements that are extremely beneficial for the United States. The course of US trade policy today is highly controversial and controversial. In light of this new course, one of the main problems has become the understanding of what is meant by the term fair trade. The subject of research of the article is the process of development of the world trading system within the WTO, which is based on the principle of non-discrimination, market liberalization, free trade, etc. The goal is an analysis of the definition of fair trade from a literal, terminological, historical and conceptual point of view. The objective is to research the concept of fair trade in general and each of its elements (unfair trade practice, fair competition and level playing field) in theoretical interpretation and in practical use. General scientific methods are used, such as system analysis - to define the general concept of fair trade and its components in theoretical and practical aspects, as well as factor analysis to formalize the cause-and-effect relationships of the investigated factors of the development of the world trade system in the direction of its liberalization. The following results were obtained: based on the analysis carried out, it can be concluded that fair trade should be understood as such trade that will exclude any manifestations of unfair trading practices, ensure fair competition, as well as a truly level playing field for trade. In practice, this is exactly what the world community is striving for in the development of the world trading system. Conclusions: the lack of a unified approach to understanding fair trade in general and each of its elements (fair trading practices, fair competition and equal conditions) allows these concepts to be manipulated and used in a way convenient for the one who uses them.
\end{abstract}

Keywords: fair trade, fair competition, level playing field, unfair trade practices.

Introduction. In the fall of 2016, the election of the 45th President of the United States was held, which was won by Donald John Trump. One of the promises of the future president during his election campaign was the withdrawal from the TransPacific Partnership (TPP), the revision of the NAFTA Agreement (North American Free Trade Agreement North American Free Trade Agreement) and support for new trade agreements that are extremely beneficial for the United States.

After Trump took office as President of the United States, the new administration developed the US President's Trade Policy Program 2017 [1], which, among others, declared the main goal of American foreign trade - expanding trade on freer and more equitable terms for all Americans.

In a memorandum for trade missions, Trump indicated on January 23, 2017 that the basis of the trade policy of the new US presidential administration will be fair and cost-effective trade deals that will serve the interests of American workers. [2].

These official documents, statements by the administration of the President of the United States and Trump himself, among other things, place the main emphasis on the so-called fair trade.

The New Deal of US Trade Policy is incredibly controversial and controversial today. In light of this 
new course, one of the main problems has become the understanding of what is meant by the term fair trade. The use of this term has its own development. The purpose of this article is to analyze the definition of fair trade from a literal, terminological, historical and conceptual point of view.

\section{Results and discussion.}

First of all, let us turn to various dictionaries. Thus, Oxford Color Russian Dictionary offers a similar translation of the word fair [3].

The Oxford Illustrated Dictionary offers the following interpretations of the word fair [4]:

- beautiful; satisfactory, abundant, attractive, pleasing, at first sight or hearing, specious, plausible;

- clean, clear, unblemished, just, unbiased, equitable, legitimate;

- of moderate quality, not bad, pretty good;

- favorable, promising, gentle, unobstructed.

A literal interpretation fairly suggested is: in a fair manner, utterly, completely, rather, tolerably.

The Longman Dictionary of contemporary English offers even more extensive interpretations of fair [5]:

- reasonable and acceptable - a situation, system, or way of treating people that is fair seems reasonable and acceptable: a fair wage for the job;

- treating everyone equally - a fair situation, judgment, description etc is one in which everyone is treated equally;

- fair person - someone who treats everyone in a reasonable, equal way;

- according to the rules - a fair fight, game, or election is one that is played or done according to the rules;

- a fair shake - fair treatment that allows someone the same chances as everyone else;

- by fair means of foul - using any method to get what you want, including dishonest or illegal methods.

Thus, we can conclude that in the understanding of the English and American dictionaries, the word fair means precisely the literal meaning of the word "fair", i.e. reasonable, impartial, equal, honest, legal. In other words, in a common sense, the term fair trade means fair or fair trade, and from this point of view, the use of the phrase "fair trade" is quite justified.

If we focus on the context of trade, then we can conclude that trade in this case should provide equal conditions for all its participants, the rules for all should be uniform and reasonable, the same. They must also be used in the same way for all traders, protect the rights of traders in the same way, and provide, accordingly, the same rights for all. In fact, such trading should give everyone an equal chance of success and, of course, should be legal. However, it should be noted that the use of the strong expression "by any means" gives this concept a negative character and implies the possibility of using dishonest and illegal methods.
The general conclusion about the literal interpretation of the concept of "fair trade", arising from the totality of the definitions discussed above, is based on the following elements:

- equal conditions in trade, legality and reasonableness of these conditions;

- honesty in a common understanding - both of the system itself in relation to its participants, and participants in relation to each other;

- uniformity, impartiality.

The literal interpretation of the term "fair trade" allows only a general understanding of what it might mean. Like any other concept, the concept of fair trade is based on certain concepts and terms that constitute the essence of this concept. To such concepts and terms, when it comes to "fair trade", in most cases, scientists refer the following three terms: unfair trade practices, fair competition and level playing field. These definitions, like fair trade, do not have an unambiguous translation or generally accepted definitions. However, each of the terms presented is interconnected with the other two and is an integral part of fair trade.

The analysis of the presented terms must begin with their translation. In this case, there is no need for a literal translation, since in the context of trade, a simple literal translation may differ in substance. Within the framework of this article, the presented terms must be translated in the context of trade. For this purpose, let us refer to the Longman Dictionary of contemporary English [5]. In it we will find a translation of the following terms: fair trade, unfair trade practices and fair competition - fair trade, dishonest / unfair policy and fair competition, respectively. The concept of level playing field was not found in this source, but it can be translated as equal conditions.

Let's dwell on each of these terms separately. Despite the fact that the presented terms are often used in international trade practice, none of them not only does not have a generally accepted definition, but is also enshrined in law. Nevertheless, different interpretations of these concepts are available in various sources, since trade issues are discussed by many national and supranational authorities and these terms are actively used. The Dictionary, which made it possible to translate some of the presented terms, also provides additional explanations for some of the terms. Thus, under fair trade, depending on the context, the glossary suggests understanding:

- a trading system with an equal balance of rights and obligations;

- trade excluding dumping;

- fair competition.

The Dictionary proposes to understand fair competition as fair competition, which implies the implementation of international trade based on the rules of the multilateral trading system on a non-discriminatory approach. 
Instead of the term unfair trade practices, the Dictionary cites the term unfair trading practices, but this does not change the essence of this concept. In any case, both terms are translated, as indicated above, as follows: unfair trade policy. In some cases (most often in legal texts), the word practices is more correctly translated as "practice", meaning "legal" or "judicial" practice [5].

The Dictionary notes that unfair trade policy, according to the WTO rules, means the unseemly or illegal use of subsidies or the export of products at dumping prices. Considering the legally binding nature of the WTO rules, it is more accurate to use the translation "unfair trade practice" in this case. At the same time, given the literal interpretation of the word "fair" or its English translation fair, it seems fair to use the phrases "unfair trade practice" and "fair competition" as a translation [5].

It is also important to note that when translating fair trade, as noted above, explanations such as "trade excluding dumping" and "fair competition" are used, i.e., based on the context, we can say that basically fair trade lies in the absence of unfair trade practices, which include dumping and export subsidies, and fair competition, which means trade based on WTO rules. At the same time, the very first possible understanding of fair trade is based on a level playing field, since fair trade is also understood as a trading system with an equal balance of rights and obligations.

Now it is necessary to turn to the WTO rules for a more complete understanding of what is meant by all of the above.

First, as already noted, fair competition implies respect for the principle of non-discrimination. This principle is well known to those who study WTO law. Non-discrimination is the most important and universal principle based on the need to create equal conditions for free competition of goods and services regardless of the country of production. Thus, the idea of equal participation of states in international trade is manifested. Based on the presented definition, in fact, the principle of non-discrimination at the official level enshrines the foundations of fair trade. This principle is based on such concepts as "equal conditions" and "free competition".

This principle was first formulated in GATT-47. It is based on two regimes: the most favored nation (MFN) (Most Favorable Nation Treatment, MFN) and the national treatment (NR) (National Treatment) [6].

NLR is enshrined in It. 1 GATT-47. Granting MFN - extending to a country to which such a regime is granted, any concessions enjoyed by any third country. In practice, this means creating equal conditions in trade with all countries to which such a regime is granted, since any concessions (privileges) should automatically apply to all other countries. There are also generally accepted exceptions to this regime, for example, customs unions (CU) and free trade areas (FTZ), as well as unilateral preferences for developing countries and countries with economies in transition, but the essence of this principle does not change. In the case of the CU and FTA, the process of integration of several countries is taking place, in economic terms, they begin to act together, which means they have the right to improved conditions for each other.

At the same time, in relation to other countries, they act either in the same way or separately, but always their concessions and obligations apply equally to all other countries. This element of the principle of non-discrimination provides protection in relation to third countries and ensures uniform terms of trade for all countries with a specific country or group of countries united by an agreement.

The national regime is enshrined in It. 3 GATT-47. Its provision involves the provision of imported goods, services and persons with a legal regime that is the same or no less favorable than that applied to goods produced domestically (for goods only after customs clearance) [6].

In accordance with this regime, all companies created on the territory of the contracting states, as well as imported goods and services, must be equal before this state in the sphere of taxation and regulation of their activities or the regime of sale. In other words, the established internal national barriers in the form of taxes, fees, laws, rules, requirements should equally apply both to national participants in trade and national goods, and to foreign participants in trade and foreign goods. This means that both national and foreign enterprises have equal conditions for their entrepreneurial activities and there is no discrimination of foreign entrepreneurs at the expense of national ones. This applies equally to foreign goods and services, which excludes discrimination within one state.

Since the establishment of the WTO, two more documents have appeared in the multilateral trading system that secure the MFN and NR GATS (General Agreement on Trade in Services It. 2 and 17, respectively) [7] and TRIPS (Agreement on Trade-Related Aspects of Intellectual Property Rights - It. 3 and 4) [8].

Thus, we can say that the principle of nondiscrimination in general form offers the legally enshrined concepts of "fair competition" and "equal conditions" in general terms.

In addition to the principle of nondiscrimination and the elements of fair trade reflected in it in the form of "equal conditions", which will be discussed in more detail below, and "fair competition", which is also understood as fair, fair and free competition, there are also general principles traced in the WTO rules, but not always clearly fixed in them.

Thus, on the official website of the WTO, a brief summary of the Principles of the Trading System 
is provided, in which, in addition to the principle of non-discrimination, four more general principles are presented:

- gradual reduction of trade barriers through negotiations;

- predictability (absence of arbitrary emergence of new trade barriers, compliance with the assumed obligations under the WTO);

- promoting fair competition (discouraging "unfair" practices in the form of dumping and export subsidies);

- support for economic development and economic reforms (support for developing and least developed countries, as well as countries with economies in transition).

As noted, "fair / fair competition", ie "fair competition", is understood as such competition, in which all participants in economic activity are provided with equal non-discriminatory conditions. The considered WTO principle gives us a more complete and accurate understanding of what is understood from the point of view of the international trading system as discriminatory conditions. These are dumping and export subsidies. However, if we go back to the terms presented in the glossary, dumping and export subsidies are examples of "unfair trade practices". Thus, we can say that the multilateral trading system as a whole formalizes the understanding of "unfair practices" as the use of dumping and export subsidies. The absence of the word "trading" in the phrase should not be misleading or embarrassing, since the WTO system is a multilateral trading system. This means that any established rules and principles apply to trading. Additional clarification that it is precisely about "unfair trading practices" is not required in this case.

The definition of "fair trade" in the glossary also, depending on the context, allows one to speak of unfairness when it comes to dumping. If dumping is a deliberate lowering of prices, then an export subsidy is a compensation for losses for national entrepreneurs. Generally speaking, both cases are related to unfair pricing, since in one case the company deliberately keeps prices low, and in the other, the company receives a refund from sales, therefore, it does not have to sell the product at a competitive price. It can compensate for its profits through a subsidy. Therefore, the absence of a mention of export subsidies in the definition of the glossary is not an oversight, as it is generally clear that, excluding dumping, any manipulation of unfair pricing must be ruled out.

Thus, it can be concluded that, in accordance with the WTO principles, dumping and export subsidies are "unfair trade practices". At the same time, it cannot be said that the variants of "unfair trading practices" are limited to this [9].

The WTO rules and their interpretation provide a seemingly very clear and complete picture of what is meant by "unfair trading practices".
However, this would only be partly true even with regard to the regulation of the multilateral trading system. In addition to dumping and export subsidies, there are many other examples of activities that, in one way or another, may be classified as "unfair trade practices". In addition, the phrase "unfair practices" is used not only in trade but also in other areas of regulation. One such area is national antitrust law or competition law.

An example of such use of this concept can be considered the "Definition of unfair trade practices", which was adopted on January 4, 2010 by the Japanese Government Commission on Fair or Fair Trade (Fair Trade Commission (Japan) [10].

This definition classifies the following actions or omissions as unfair trading practices:

- agreed refusal to trade;

- other biased cases of refusal to trade;

- discriminatory remuneration;

- discriminatory treatment;

- discriminatory attitude within the trade association;

- unfair prices (high or low);

- misleading a partner;

- offering unfair favorable terms;

- related sales;

- trade on exclusive terms;

- trading on restrictive terms;

- interference with the management of a competing company;

- interference in a competitor's transactions;

- interference with the internal activities of a competing company.

As noted, this approach is primarily associated with the regulation of competition at the national level, i.e. belongs to the sphere of national antitrust law. At the same time, such additional rules at the national level of regulation make it possible to more accurately understand what is understood in certain countries by "unfair trade practices". This, in turn, provides an opportunity for further unification of international regulation in the establishment of more equitable generally accepted norms and principles of the multilateral trading system.

Unfair trading practices and fair competition are inextricably linked. "Unfair trading practices" includes violations of the terms of "fair competition". And "fair competition" is ensured by the absence of "unfair trading practices." This approach, when "unfair trade practices" is equated with antitrust and competition law, focuses mainly on the rights and obligations of legal entities. This approach dominated at the very beginning of the development of the concept. In the future, this dominance, although it remained, since the main emphasis of regulation in the field of fair trade was made precisely on the rules for legal entities and their operating activities. However, over time, new regulatory issues have become increasingly common. These primarily include issues of compliance with consumer rights. 
A contemporary example of defining "unfair trade practices" through respect for consumer rights is the Barbados Fair Trade Commission Guidelines [11]. In accordance with the document under consideration, legal entities are prohibited from carrying out any activity related to misleading the consumer, for example, providing false information about the type, quality, packaging of goods, about its consumer characteristics, about the price of goods, etc. This approach contains essentially similar prohibitions, but in fact they relate to the relationship between the entrepreneur and the consumer. At the same time, the previously considered approach used in Japan and Russia focuses on the regulation of relations between legal entities, i.e. entrepreneurs, as well as between them and the authorities.

Many dictionaries and international law firms define "unfair trade practices" based on the need to protect consumer rights. For example, the Meriam-Webster dictionary offers as a definition of "unfair trade practice" any act (or omission) that is fraudulent, misleading, causes all kinds of harm to the consumer, or it is any regulatory legal act that violates the rights of citizens or restricts their legal rights [12].

A similar definition can be found on the official website of the international law firm Winston \& Strawn LLP, which by unfair trading practice means any business practice or regulation that is fraudulent, misleading or damaging the consumer. Examples of such practices may be illegal actions in the form of violation of consumer protection laws, or false descriptions of a product or service, non-existent promotions or prize draws, noncompliance with technical or production standards, deceptive advertising, price speculation, etc. [13].

Based on the proposed analysis of various approaches to the definition of "unfair trading practices", the following conclusion can be drawn.

In a broad sense, any unfair or dishonest behavior of any persons towards each other in the course of their economic activities, the result of which will be a violation of either someone's rights or obligations assumed, can be classified as "unfair trade practices". In a narrower sense, "unfair trade practices" will be understood as a specific violation of international law or regulation. Moreover, in the case of fair trade, it is the broad interpretation of this concept that seems more preferable. The reason for this is, first of all, the fact that today only the most general concept of "unfair trade practices" has been established at the official level. As already mentioned, in the case of the WTO, this is dumping and export subsidies. However, these are only the most common cases of "unfair trading practices".

In addition, as has been noted many times, "unfair trade practices" are inextricably linked with the terms "fair competition" and "equal conditions", without which it is impossible to understand it, just as it is impossible to understand fair trade without understanding unfair trading practices.

Of the three basic elements of fair trade, the level playing field stands apart.

"Equal conditions" was already referred to as "non-discriminatory" conditions when the definition of "fair competition" was introduced. The concept of "equal playing field" is directly related to the concept of equal opportunity "equal opportunities" (Conception of equal opportunity "the level playing field ideal"). This concept was proposed by J. Roemer in 1995 [14]. In accordance with it, equal conditions exist when they provide equal opportunities both for achieving success and for obtaining a negative result. On the one hand, this can be achieved by removing legal barriers to social mobility by the government and by creating conditions under which only the most successful and efficient workers will occupy positions.

On the other hand, this situation is achieved by ensuring equal access of citizens to educational services, as well as to other social services and opportunities that society can offer. J. Roemer believed that equal conditions in any case will lead to unequal distribution of resources and that this distribution should be based on the ability of the individual to take responsibility for their own activities, i.e. it depends only on the individual how much he can get. The development of the personality, in any case, distinguishes it in any sphere of activity and elevates it above the rest, allowing such an individual to receive more in all senses [14].

In 2015, two other social scientists R. Arnerson and E. Zalta proposed their vision of this concept. They published a study "Equality of Opportunities" [15], in which they interpreted the ideas of $\mathrm{J}$. Roemer as follows. "Equal conditions "are equal starting opportunities that provide people with a kind of necessary" start-up capital "for organizing their own business, which is understood as the development of their own personality. In this case, only his own choice and the responsibility of a particular individual determine his path of development".

The approach under consideration is philosophical, and its roots lie in sociology. At the same time, the main thing that needs to be understood from the explanations presented is that "equal conditions" are understood not literally as identical, but there are certain deviations from the literal understanding of the word "equal".

Arnerson and Zalta's interpretation of this concept coincides with the interpretation given in the Cambridge Dictionary, which implies a situation in which everyone has an equal chance of success.

Another similar interpretation, closer to the sphere of trade, is given by the online directory of the Financial Times Lexicon. According to this guide, "level playing field" is defined as the same conditions of competition in the market or industry, regulation and taxation. 
Using this concept means supporting a multilateral trading system based on the principle of non-discrimination, liberalization of markets, free trade, etc. At the same time, on the one hand, this concept serves as a basis for stimulating the emergence of more liberal regulatory measures that would promote competition and reduce the pressure of imperative regulation on the economy, and on the other hand, in practice, this concept makes it possible to establish mutual measures to protect national markets and create additional barriers that burden those entrepreneurs who do not comply with the principles of free trade.

"Level playing field" is also considered from an economic point of view. For example, in the work "Equal Rules or Equal Opportunities? Clarification of equal conditions ", two variants of the definition of" equal conditions "are proposed [16].

The first focuses on the established rules of the game and explains that "level playing field" will be considered equal rules for all players. In other words, these rules will apply to everyone and everyone equally. The second definition is based on possible outcomes, i.e. "Level playing field" is defined as an environment under which companies can obtain the same expected profit. The second definition is more stringent, since it actually limits the opportunities for development to the same possible reward.

From the point of view of international trade, a good definition of "level playing field" is given in the work of A. Deardorff [17], which provides an example of the US and EU aviation industry. To achieve a "level playing field" between the US and EU aviation industries are subsidized.

To be on a level playing field, other countries with their own aviation industries must also subsidize national production.

Consequently, the concept of "level playing field", like "unfair trading practices", can be interpreted broadly or narrowly. In a broad sense, this is ensuring equal conditions at the initial stages of the development of something. In a narrow sense, everything depends on the area in question. In trade, the conditions that ensure the unity of the multilateral trading system will be considered equal. In fact, equal conditions will include the observance of the principle of non-discrimination, nonadmission by all traders to the equal use of "unfair trade practices" and the creation of uniform conditions for maintaining "fair competition".

\section{Conclusion.}

Thus, a detailed analysis of the considered concepts shows how much they are interconnected. In fact, non-compliance with even one of these elements immediately threatens compliance with the rest. At the same time, the joint observance of all analyzed concepts makes it possible to get as close as possible to the modern understanding of fair trade.

The concepts discussed are building blocks of fair trade. However, the lack of a common approach to understanding fair trade in general and each of its elements (fair trade practices, fair competition and level playing field) allows these concepts to be manipulated and used in a way that suits the person using them.

As for the definition of fair trade, based on the analysis carried out, we can conclude that fair trade should be understood as such trade that will exclude any manifestations of unfair trade practices, ensure fair competition, as well as truly equal conditions for trade. In practice, this is exactly what the world community is striving for in the development of the world trading system. However, in the absence of a clear idea of what the development is for, it is easy to make wrong decisions, which will then be very difficult to correct. Perhaps that is why there are no definitions of the concepts under consideration officially adopted at the level of the multilateral trading system.

\section{ЗАГАМЬНА КОНЦЕПЦІЯ І КОМПОНЕНТИ СПРАВЕДАИВОЇ ТОРГІВАІ: ТЕОРІЯ I МІЖНАРОДНА ПРАКТИКА}

Довгахь Охена Андріївна, докт. екон. наук., професор, Харківський національний університет імені В. H. Каразіна, мн. Свободи, 6, м. Харків, Україна, 61022, e-mail: e.dovgal@karazin.ua; ORCID: https://orcid.org/0000-0003-3219-9731

Довгамь Георгій Вомодимирович, канд. екон. наук, доцент, Харківський національний університет імені В. Н. Каразіна, м. Свободи, 6, м. Харків, Україна, 61022, e-mail: g.dovgal@karazin.ua, ORCID https://orcid.org/0000-0002-0644-1793

Актуальність дослідження обумовлена тим, що з 2017 року офіційні документи і заяви адміністрації США, крім іншого, роблять основний акцент на так званій справедливій торгівлі. Новий курс торгової політики США є на сьогоднішній день досить спірним і суперечливим. У світлі цього нового курсу однією 3 основних проблем стало усвідомлення того, що розуміється під терміном справедливої торгівлі. Предметом дослідження статті є процес розвитку світової системи торгівлі в рамках СОТ, в основі якого межить принцип недискримінації, мібералізація ринків і вільна торгівля. Метою статті є аналіз дефініції справедливої торгівлі з буквальної, термінологічної, історичної та концептуальної точок зору. Завданнями - дослідження поняття справедиивої торгівлі в цілому і кожного ії елемента (несправедлива торгова практика, справедлива конкуренція і рівні умови) в теоретичному тлумаченні і в практичному використанні. Використовуються загальнонаукові методи, такі як системний аналіз - дмя визначення загального поняття справедливої торгівлі та її складових у теоретичному і практичному аспектах, а також факторний аналіз - для формалізації причинно-наслідкових зв'язків досліджуваних факторів світової 
системи торгівлі в напрямку їі цібералізації. Були отримані наступні результати: виходячи з проведеного аналізу можна зробити висновок про те, що під справедливою торгівлею слід розуміти таку торгівлю, яка виключатиме будь-які прояви несправедливої торгової практики, передбачає справедливу конкуренцію, а також дійсно рівні умови дмя здійснення торгівлі. На практиці саме до цього прагне світове співтовариство в процесі розвитку світової торгової системи. Висновки: відсутність єдиного підходу до справедливої торгівці в цілому і кожного ї̈ елемента дозволяє маніпулювати цими поняттями і використовувати їх так, як зручно тому, хто ними користується.

КАючові слова: справедлива торгівля, справедлива конкуренція, рівні умови, несправедлива торгова практика.

\section{ОБЩАЯ КОНЦЕПЦИЯ И КОМПОНЕНТЫ СПРАВЕДАИВОЙ ТОРГОВАИ: ТЕОРИЯ И МЕЖДУНАРОДНАЯ ПРАКТИКА}

Довгахь Емена Андреевна, докт. экон. наук, профессор, Харьковский национальный университет имени В. Н. Каразина, пл. Свободы, 6, г. Харьков, Украина, 61022, e-mail: e.dovgal@karazin.ua; ORCID https://orcid.org/0000-0003-3219-9731

Довгамь Георгий Вмадимирович, канд. экон. наук, доцент, Харьковский национальный университет имени В. Н. Каразина, пл. Свободы, 6, г. Харьков, Украина, 61022, e-mail: g.dovgal@karazin.ua, ORCID: https://orcid.org/0000-0002-0644-1793

Актуальность исследования обусловлена тем, что с 2017 года официальные документы и заявления администрации США, помимо прочего, делают основной акцент на так называемой справедливой торговле. Новый курс торговой политики США явцяется на сегодняшний день весьма спорным и противоречивым. В свете этого нового курса одной из основных проблем стало осознание того, что понимается под термином справедливой торговли. Предметом исследования статьи явцяется процесс развития мировой системы торговли в рамках ВТО, в основе которого межит принцип недискриминации, миберализация рынков и свободная торговля. Целью статьи является анализ дефиниции справедливой торговли с буквальной, терминологической, исторической и концептуальной точек зрения. Задачами исследование понятия справедливой торговли в целом и каждого ее элемента (несправедливая торговая практика, справедливая конкуренция и равные условия) в теоретическом толковании и в практическом использовании. Используются общенаучные методы, такие как системный анализ - для определения общего понятия справедливой торговли и ее составляющих в теоретическом и практическом аспектах, а также факторный анализ - для формализации причинно-следственных связей исследуемых факторов мировой системы торговли в направлении ее миберализации. Были получены следующие результаты: исходя из проведенного анализа можно сделать вывод о том, что под справедливой торговцей следует

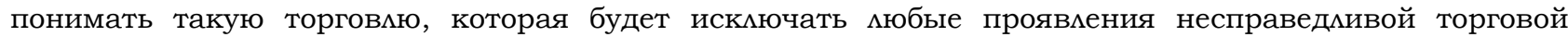
практики, подразумевает справедливую конкуренцию, а также действительно равные условия дмя осуществления торговли. На практике именно к этому стремится мировое сообщество в процессе развития мировой торговой системы. Выводы: отсутствие единого подхода к справедливой торговце в целом и каждого ее элемента позволяет манипулировать этими понятиями и использовать их так, как удобно тому, кто ими пользуется.

Кмючевые слова: справедливая торговля, справедиивая конкуренция, равные условия, несправедиивая торговая практика.

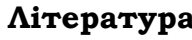
1. The
President's
2017
Trade
Policy
Agenda.
URL:

https://ustr.gov/sites/default/files/files/reports/2017/AnnualReport/Chapter\%20I\%20-

\%20The\%20President\%27s\%20Trade\%20Policy\%20Agenda.pdf.

2. Presidential Memorandum Regarding Withdrawal of the United States from the Trans-Pacific Partnership Negotiations and Agreement, 23.01.2017: URL: https://www.whitehouse.gov/presidentialactions / presidential-memorandum-regarding-withdrawal-united-states-trans-pacific-partnershipnegotiations-agreement/.

3. Thompson D. Oxford Colour Russian Dictionary. Oxford: Oxford University Press. 1998.

4. Oxford Illustrated Dictionary. Oxford: Oxford at the Clarendon Press. 1970.

5. Longman Dictionary of contemporary English. Pearson Education Limited. 2000.

6. WTO. Marrakesh Protocol to the General Agreement on Tariffs and Trade 1994. URL: https://www.wto.org/english/docs_e/legal_e/13-mprot_e.htm

7. WTO. General Agreement on Trade in Services. URL: https://www.wto.org/english/docs_e/legal_e/26gats_01_e.htm

8. WTO. Trade-Related Aspects of Intellectual Property Rights. URL: https://www.wto.org/english/docs_e/legal_e/27-trips_01_e.htm

9. WTO. What we stand for. URL: https://www.wto.org/english/thewto_e/whatis_e/what_stand_for_e.htm

10. Designation of Unfair Trade Practices (Fair Trade Commission Public Notice. No. 15 of June 18, 1982). URL: http://www.jftc.go.jp/en/legislation_gls/unfairtradepractices.html.

11. The Consumer Protection Act: Unfair trade practices (guidance). Fair Trading Commission of Barbados. 2003 
12. Law Dictionary, Merriam-Webster. URL: https://www.merriamwebster.com/legal/unfair\%20trade\%20practice.

13. What are Unfair Trade Practices? Winston\&Strawn LLP. URL: https://www.winston.com/en/legalglossary/unfair-trade-practices.html.

14. Roemer J. Equality and Responsibility. Boston Review. 1995. April-May Issue, 3-7.

15. Arneson R. Equality of Opportunity, The Stanford Encyclopedia of Philosophy E.N. Zalta (ed.). 2015. URL: https://plato.stanford.edu/archives/sum2015/entries/equal-opportunity/.

16. Appelman M., Gorter J., Lijesen M., Onderstal S., Venniker R. Equal Rules or Equal Opportunities? Demystifying Level Playing Field. CPB Netherlands Bureau for Economic Policy Analysis. 2003. October.

17. Deardorff A.V. Economic Effects of "Leveling the Playing Field" in International Trade, University of Michigan. Journal of International Trade and Economic Development. 2010. March, No. 19(1). 9-32.

\section{References}

1. The President's 2017 Trade Policy Agenda. Available https://ustr.gov/sites/default/files/files/reports/2017/AnnualReport/Chapter\%20I\%20-

\%20The\%20President\%27s\%20Trade\%20Policy\%20Agenda.pdf.

2. Presidential Memorandum Regarding Withdrawal of the United States from the Trans-Pacific Partnership Negotiations and Agreement, 23.01.2017: Available https://www.whitehouse.gov/presidential-actions/presidential-memorandum-regarding-withdrawal-unitedstates-trans-pacific-partnership-negotiations-agreement/.

3. Thompson D. (1998). Oxford Colour Russian Dictionary. Oxford: Oxford University Press.

4. Oxford Illustrated Dictionary. (1970). Oxford: Oxford at the Clarendon Press.

5. Longman Dictionary of contemporary English. (2000). Pearson Education Limited.

6. WTO. Marrakesh Protocol to the General Agreement on Tariffs and Trade 1994 Available at: https://www.wto.org/english/docs_e/legal_e/13-mprot_e.htm
7. WTO. General Agreement on Trade

https://www.wto.org/english/docs_e/legal_e/26-gats_01_e.htm

8. WTO. Trade-Related Aspects of Intellectual

https://www.wto.org/english/docs_e/legal_e/27-trips_01_e.htm
9. WTO.
What
we
stand

in Services

Available

at:

https://www.wto.org/english/thewto_e/whatis_e/what_stand_for_e.htm

10. Designation of Unfair Trade Practices (Fair Trade Commission Public Notice. No. 15 of June 18, 1982). Available at: http://www.jftc.go.jp/en/legislation_gls/unfairtradepractices.html.

11. The Consumer Protection Act: Unfair trade practices (guidance). Fair Trading Commission of Barbados, 2003.

12. Law Dictionary, Merriam-Webster.

webster.com/legal/unfair\%20trade\%20practice.

13. What are Unfair Trade Practices? Winston\&Strawn LLP. Available at: https://www.winston.com/en/legal-glossary/unfair-trade-practices.html.

14. Roemer J. (1995). Equality and Responsibility. Boston Review. April-May Issue, 3-7.

15. Arneson R. (2015. Equality of Opportunity, The Stanford Encyclopedia of Philosophy E.N. Zalta (ed.). Available at: https://plato.stanford.edu/archives/sum2015/entries/equal-opportunity/.

16. Appelman M., Gorter J., Lijesen M., Onderstal S., Venniker R. (2003). Equal Rules or Equal Opportunities? Demystifying Level Playing Field. CPB Netherlands Bureau for Economic Policy Analysis, October.

17. Deardorff A.V. (2010). Economic Effects of "Leveling the Playing Field" in International Trade, University of Michigan. Journal of International Trade and Economic Development, March, No. 19(1), 9-32. 